University of Nebraska - Lincoln

DigitalCommons@University of Nebraska - Lincoln

Papers in the Earth and Atmospheric Sciences

Earth and Atmospheric Sciences, Department

$12-2018$

\title{
Seismicity in Nebraska and adjacent states: The historical perspective and current trends
}

Irina Filina

University of Nebraska - Lincoln, ifilina2@unl.edu

Kris Guthrie

University of Nebraska-Lincoln

Mindi Searls

University of Nebraska-Lincoln, msearls2@unl.edu

Caroline M. Burberry

University of Nebraska-Lincoln, cburberry2@unl.edu

Follow this and additional works at: https://digitalcommons.unl.edu/geosciencefacpub

Part of the Earth Sciences Commons

Filina, Irina; Guthrie, Kris; Searls, Mindi; and Burberry, Caroline M., "Seismicity in Nebraska and adjacent states: The historical perspective and current trends" (2018). Papers in the Earth and Atmospheric Sciences. 675.

https://digitalcommons.unl.edu/geosciencefacpub/675

This Article is brought to you for free and open access by the Earth and Atmospheric Sciences, Department of at DigitalCommons@University of Nebraska - Lincoln. It has been accepted for inclusion in Papers in the Earth and Atmospheric Sciences by an authorized administrator of DigitalCommons@University of Nebraska - Lincoln. 


\title{
Seismicity in Nebraska and adjacent states: \\ The historical perspective and current trends ${ }^{1}$
}

\author{
IRINA FILINA ${ }^{2}$ \\ MINDI SEARLS ${ }^{2}$
}

KRIS GUTHRIE ${ }^{2}$

CAROLINE M. BURBERRY²

1. Manuscript submitted September 21, 2018; Accepted October 25, 2018

2. The Department of Earth and Atmospheric Sciences, The University of Nebraska at Lincoln, Lincoln, NE 68588

\begin{abstract}
A sudden spike in earthquake events has been observed in central Nebraska. Since April 2018, 26 earthquakes with equivalent moment magnitudes from 2.7 to 4.1 occurred, clustered tightly in Custer County. A similar cluster of 24 earthquakes with equivalent moment magnitudes from 2.6 to 3.7 occurred in Jewell County in northern Kansas in 2017. We have compiled an earthquake database for Nebraska and parts of adjacent states from different sources to determine whether these recent earthquake spikes are consistent with historic seismicity. We identified two historic earthquake clusters occurring in our study area. The first contained 32 events and was active in Red Willow County in southwestern Nebraska from 1977 to 1982. As it coincides spatially with the Sleepy Hollow oil field, it may be related to enhanced oil recovery from that field, although it is also located at the edge of the Chadron-Cambridge Arch. The second historical earthquake cluster is located in Pawnee and Richardson counties in southwestern Nebraska and includes eight earthquakes with equivalent moment magnitudes of 2.3 to 2.8 that occurred in a period from 1982 to 1989 over the Nemaha uplift and appear to be related to the Humboldt fault. We note an increase in both maximum magnitude, as well as in the cumulative seismic moment per cluster with time. We have also used gravity and magnetic fields to map potential basement faults in the study area. Our analysis shows that the two recent earthquake spikes are aligned with the proposed basement faults. Despite this correlation, the cause of this sudden spike in seismicity is not well understood, as the stresses that might reactivate these basement faults are unknown. In addition, both recent clusters are distant from oil and gas operations. More seismic stations are necessary in central Nebraska in order to better detect focal depths and faulting style in the ongoing cluster of earthquakes and investigate possible causes.
\end{abstract}

INTRODUCTION...

SEISMICITY IN NEBRASKA AND ADJACENT STATES

218

INTEGRATED ANALYSIS OF GRAVITY

AND MAGNETIC FIELDS
DISCUSSION. .225

CONCLUSIONS.
ACKNOWLEDGEMENTS.

REFERENCES

. .227

..228




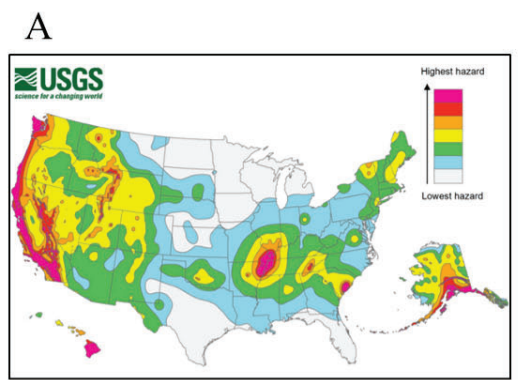

$\mathrm{B}$

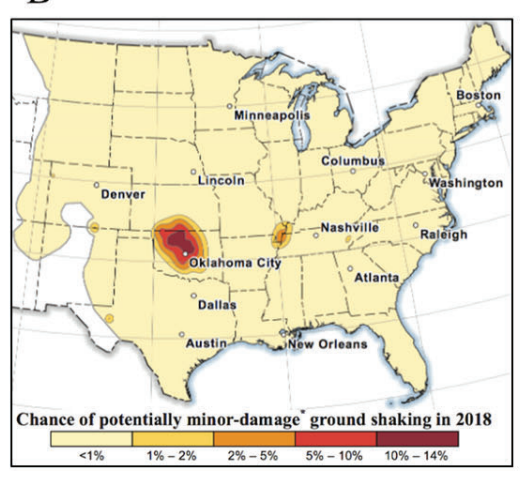

$\mathrm{C}$

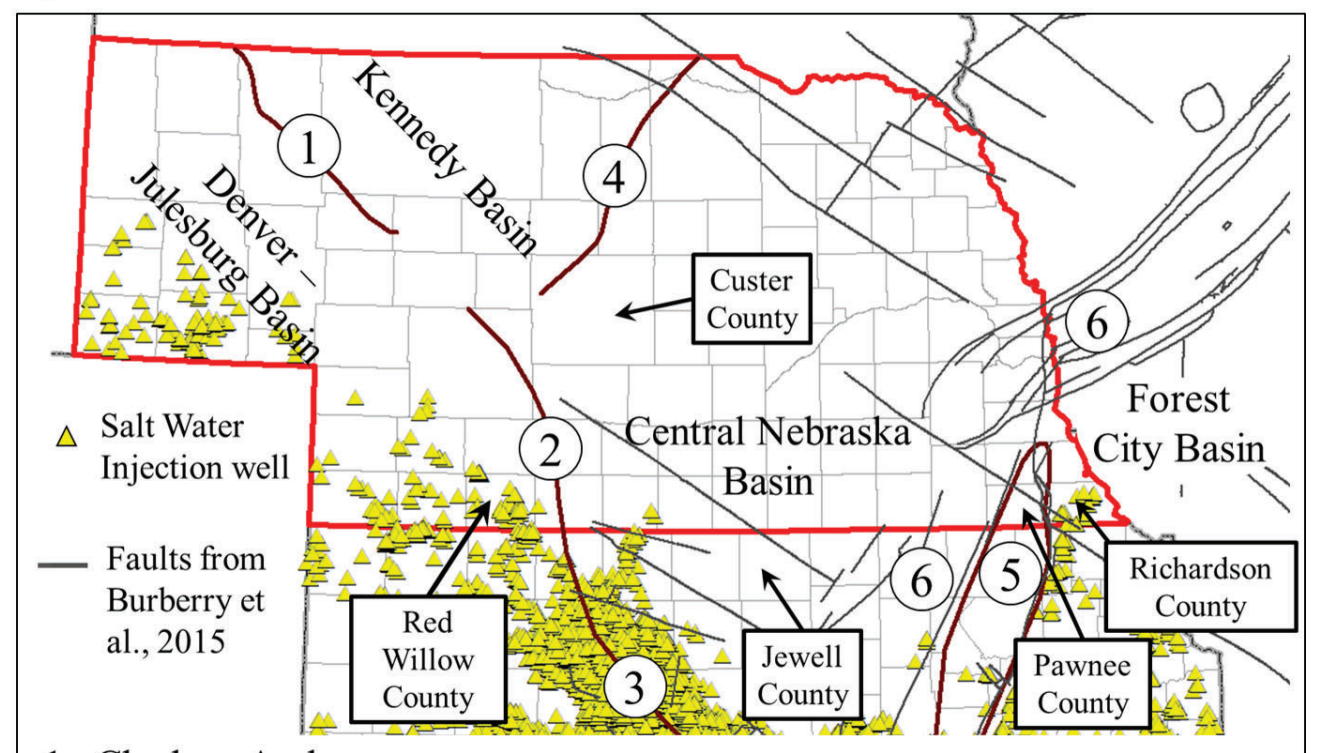

1 Chadron Arch

2 Cambridge Arch
3 Central Kansas Uplift

4 Siouxana Arch
5 Nemaha Ridge 6 Midcontinent Rift

Figure 1. (A) Simplified version of the United States National Seismic Hazard Map (Petersen et al., 2014); (B) Short-term induced seismicity forecast for 2018 (Petersen et al., 2018), (C) Major tectonic elements for the study area digitized from Burchett (1990), Rothe and Lui (1983) and Burberry et al. (2015). Yellow triangles show salt water disposal wells from the Nebraska Oil and Gas Conservation commission (http:// www.nogcc.ne.gov//) and from the Kansas Geological Survey (http://www.kgs.ku.edu/).

\section{INTRODUCTION}

The state of Nebraska is traditionally considered an aseismic region. The United States Geological Survey (USGS) uses the historic seismicity data from both tectonic and potentially induced sources to prepare probabilistic seismic hazard maps. The latest version of this map (Petersen et al., 2014) suggests the lowest seismic hazard for a large portion of the state of Nebraska (Fig. 1A). The one year forecast for induced seismicity published by USGS for 2018 (Petersen et al., 2018) also does not show any expected seismic hazards in the region (Fig. 1B). Despite these hazard forecasts, a swarm of 27 earthquakes was recorded in Nebraska between April and October of this year with all but one of them tightly clustered in a $18 \mathrm{~km}$ long and $9 \mathrm{~km}$ wide region in Custer County in the central part of the state (Fig. 1C). A similar earthquake cluster was recorded in northern Kansas in 2017 with a total of 24 earthquakes occurring in Jewell County in a region $17 \mathrm{~km}$ long and $3 \mathrm{~km}$ wide (Fig. 1C). We have composed a database of earthquakes in Nebraska and adjacent states since 1867 with the objective to assess if similar clustered seismicity has occurred in the past.

Figure $1 \mathrm{C}$ shows the major tectonic elements in our study area. The most prominent geological feature in the northwest is the Chadron Arch that separates the Denver - Julesburg Basin in the west and the Kennedy Basin in the north. The arch continues to the southeast as the Cambridge Arch, then bends to the south and eventually meets the Central Kansas Uplift. The Siouxana Arch bounds the Central Nebraska Basin (as in Burchett, 1990) in the north. Coleman and Gahan (2012) refer to the latter as the Salina Basin. The Midcontinent Rift is in the southeastern part of the study area along with the Nemaha Uplift and the Forest City Basin. The Humboldt Fault marks the western edge of the Nemaha Uplift. According to the Nebraska Geological Survey (http://snr.unl.edu/ data/geographygis/geology.aspx), the depth to the basement varies from $1,000 \mathrm{ft}(304 \mathrm{~m})$ over the Nemaha uplift to approximately $3,500 \mathrm{ft}(1.07 \mathrm{~km})$ over the Arches; it increases to $4,500 \mathrm{ft}(1.22 \mathrm{~km})$ in the Kennedy and 
Central Nebraska basins, and reaches $9,500 \mathrm{ft}(2.9 \mathrm{~km})$ in the Denver-Julesburg Basin in western Nebraska near the boundary with Colorado and Wyoming. Figure 1C also shows the location of the basement faults from the study of Burberry et al. (2015) that was focused on the Nemaha tectonic zone and Midcontinent Rift System in southeastern Nebraska and Northern Kansas.

Petroleum extraction operations, such as injection of produced water back to the subsurface, are known to cause dramatic seismicity in Oklahoma and southern Kansas (Keranen et al., 2013; Walsh and Zoback, 2015; Rubinstein et al., 2018; Hincks et al., 2018; Peterie et al., 2018). Locations of saltwater disposal wells compiled by the Nebraska Oil and Gas Conservation commission (http:// www.nogcc.ne.gov/) and the Kansas Geological Survey (http://www.kgs.ku.edu/) are shown as yellow triangles in Figure 1C. The induced earthquakes in Oklahoma are linked to reactivation of shallow basement faults, the majority of which were mapped by traditional subsurface methods (i.e., Marsh and Holland, 2016). In addition, some of the basement faults were inferred from examination of multiple earthquakes (McNamara et al., 2015), as well as through interpretation of airborne magnetic data (Shah and Crain, 2018). As we have not found published fault maps for the state of Nebraska other than the ones from Burberry and others (2015; Fig. 1C), we performed an analysis of potential fields in our study area to map possible faults in the basement and to check whether they correlate to the observed seismicity. In our analysis, we have used both gravity and magnetic data simultaneously in order to increase the confidence of our interpretation.

\section{SEISMICITY IN NEBRASKA AND ADJACENT STATES}

For our study, we compiled a database of all documented earthquakes from multiple sources for Nebraska and parts of adjacent states. We included the earthquakes from the USGS online earthquake catalog (https://earthquake.usgs.gov), the International Seismological Centre (ISC) Bulletin (http://www.isc.ac.uk), the North American Moment Tensor catalog from Saint Louis University (SLU; http://www.eas.slu.edu/eqc/), older Nebraska earthquake catalogues (Rothe and Lui, 1983; Burchett, 1990) and articles from local newspapers (the Lincoln Journal Star). Overall, our database includes 237 earthquakes (Fig. 2) that were found for Nebraska and parts of adjacent states since 1867 . The largest earthquakes occurred on November 15, 1877 (intensity VII on the Modified Mercalli Intensity scale) and on March 28, 1964 (magnitude 5.1 of the Richter scale, intensity VII). The first earthquake in our database that was recorded by a seismometer occurred in 1964. Our database also includes 91 events from 1977 to 1989 from a dedicated microearthquake study in Nebraska (Burchett, 1990). The shallowest focal depth in our database is $0.25 \mathrm{~km}$, while the deepest one is $22.3 \mathrm{~km}$. The depth of earthquakes is the most uncertain parameter, especially if the recording network is sparse. Most of the old historic events in our database do not have depths determined at all (44 earthquakes from 1867 to 1970s). In addition, 113 events have a depth of $5.0 \mathrm{~km}$. This depth is artificial as it is used by the USGS to show that the data does not constrain the depth of shallow earthquakes satisfactorily.

\section{Temporal Seismicity Trends}

The distribution of earthquakes through time is illustrated in Figure 3, where several temporal patterns are easily seen. In the 1970s, the number of earthquakes appears to increase significantly, as during this time the USGS deployed a seismometer network to record seismic activity throughout the country. Another spike in seismicity appears in the 1980s due to the aforementioned microseismicity study. The small magnitude earthquakes in that study also caused a drop in the average magnitude for that decade (Fig. 3B). There are two pronounced spikes in the current decade with 26 events in 2017, and 27 earthquakes in 2018 (as of October 22, 2018).

The magnitudes of the earthquakes are shown in Figure 3C. Our database comprises events with a multitude of magnitude types. The values for the events recorded before the first seismometer registration (i.e., 1964) were converted from the reported Modified Mercalli scale intensity to the Richter scale magnitude (ML) values using a chart from Burchett (1990). This chart lists a range of magnitudes for each intensity, so the median value was determined and assigned as the representative magnitude for the event. The majority of the events recorded in the 1970s through the 1980s use the duration magnitude (Md) that is based on the duration of shaking. Since the 1990s, most of the earthquakes in our database are reported using the MLg magnitude scale that is based on the amplitude of recorded surface waves. The majority of 


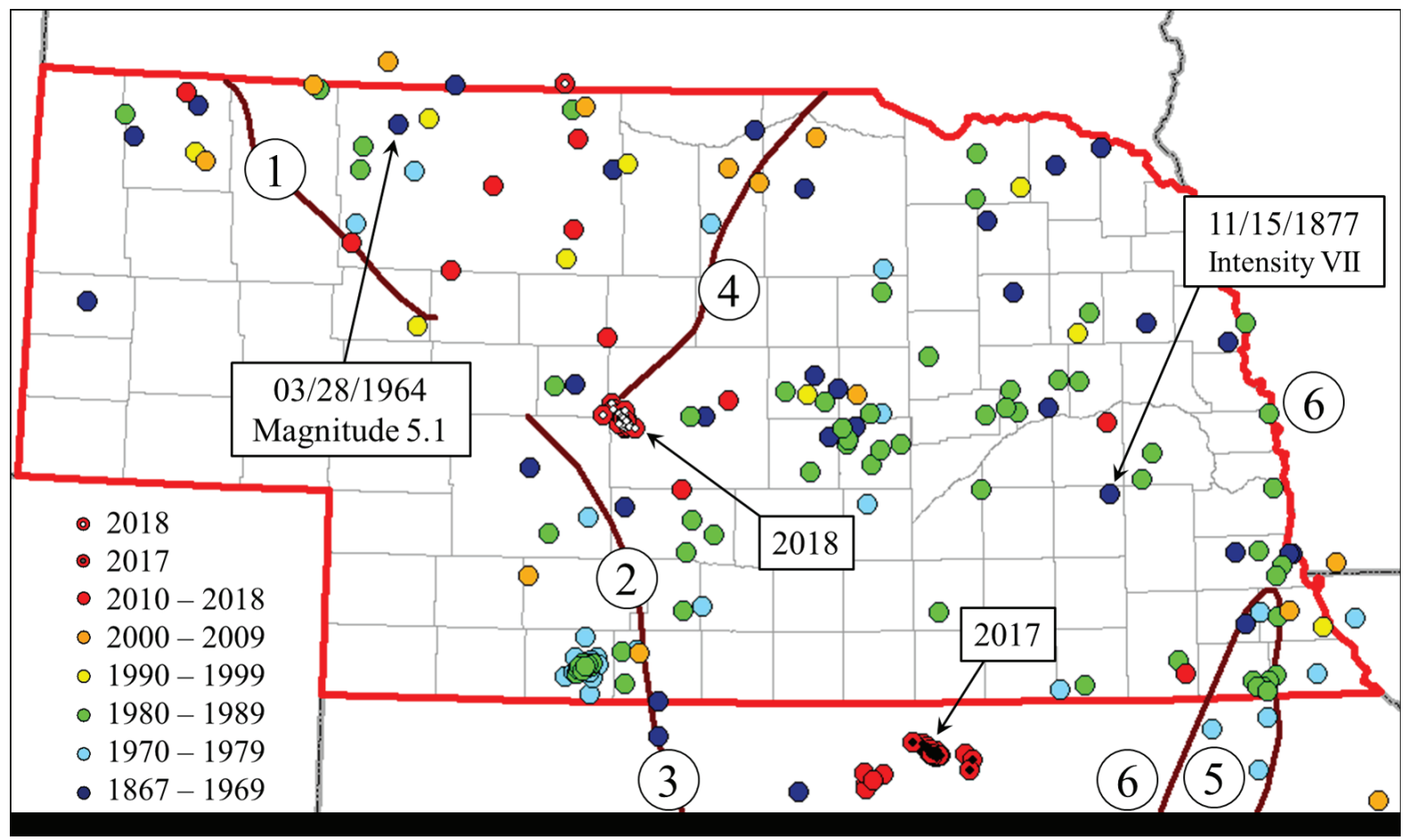

Figure 2. Earthquakes in Nebraska and adjacent states color-coded by decade. The location of major tectonic elements from Figure 1 is marked. The two largest historic events as well as the two recent seismicity clusters are labeled.

magnitudes of the recent earthquakes in 2017 and 2018 also are reported on the MLg scale, although some use $\mathrm{ML}$, and some have the regional moment magnitude Mwr listed as well. Thus, to be able to compare these events, we have used the conversion relationships from Mueller and others (1997) to convert the magnitudes of all of the records into equivalent moment magnitudes. The minimal equivalent moment magnitude of the earthquakes prior to the first seismic record was 2.8. Figure 3 reports two values for each category: the blue bars show the parameters for the entire database, while the red bars relate only to the events above magnitude 2.8. This is done to account for the apparent anomalies observed due to differences in the registration after 1964. This filtering resulted in numerical and magnitude patterns with fewer apparent anomalies, although the overall increase in the number of earthquakes throughout the last several decades is apparent.

\section{Earthquake Clusters}

Figure 4 shows all focal mechanisms developed by the USGS and SLU for the earthquakes in our database.
It is immediately clear that not all of the recorded earthquakes have solutions for moment tensors with sufficient confidence to develop focal mechanisms. This is because the magnitudes of the earthquakes are relatively small, so the records at the distant stations are insufficiently robust to be included in the moment tensor calculations. Four earthquake clusters were identified; they are highlighted in Figure 4 and summarized in Table 1. We have computed the cumulative seismic moment for each cluster using the equation from Kanamori (1978). We noticed the increase in a maximum cluster magnitude with time, as well as the dramatic increase in the cumulative seismic moment per cluster (Table 1). However, we also note that these clusters are in different areas with different geological settings.

The oldest cluster in our database includes 32 events that occurred from December 1, 1977 to May 9, 1982 in Red Willow County in southern Nebraska (Figs. 1C, 4). The equivalent moment magnitudes of the events range from 1.5 to 3.1 and the depths are between 0.57 and 11.09 $\mathrm{km}$ with the majority of the earthquakes at depth less than five kilometers. Most of these earthquakes are reported by 
Burchett (1990) and are not recorded in the USGS catalog, so no waveforms for these events are available through USGS for further analysis. This cluster is generally aligned with the western flank of the Cambridge Arch (Fig. 1C), but it also appears to be coincident with Nebraska's largest oil accumulation, the Sleepy Hollow oil field. Water injection has been used as a method of enhanced recovery from that field since 1966. The microearthquake study in northwestern Kansas and southwestern Nebraska was conducted to test possible relations between the water injection and observed seismicity (Rothe and Lui, 1983; Evans and Steeples, 1987; Burchett, 1990). The initial phase of this study (Rothe and Lui, 1983) reported 31 detected earthquakes in 1979-1980 with 16 of those occurring in the immediate vicinity of the Sleepy Hollow Field. A combined focal mechanism was developed based on records from the two largest earthquakes occurring in June and July of 1979 . The determined sense of motion was almost purely strike-slip with a right-lateral NE-SW striking fault being the most likely interpretation. However, the tectonic origin of the earthquakes was not ruled out due to the study of Stanley and Wayne (1972) which suggested early Pleistocene uplift along the axis of the Cambridge Arch based on a fluvial sediment dispersal analysis. Further results from that microseismicity experiment published by Evans and Steeples (1987) also concluded that the recorded high level of clustered microseismic events over the Sleepy Hollow oil field may be related to the enhanced oil recovery. The majority of the recorded earthquakes had focal depths less than $4 \mathrm{~km}$ with the deepest event being at a depth of 9 $\mathrm{km}$. Approximately one third of the recorded earthquakes were attributed to
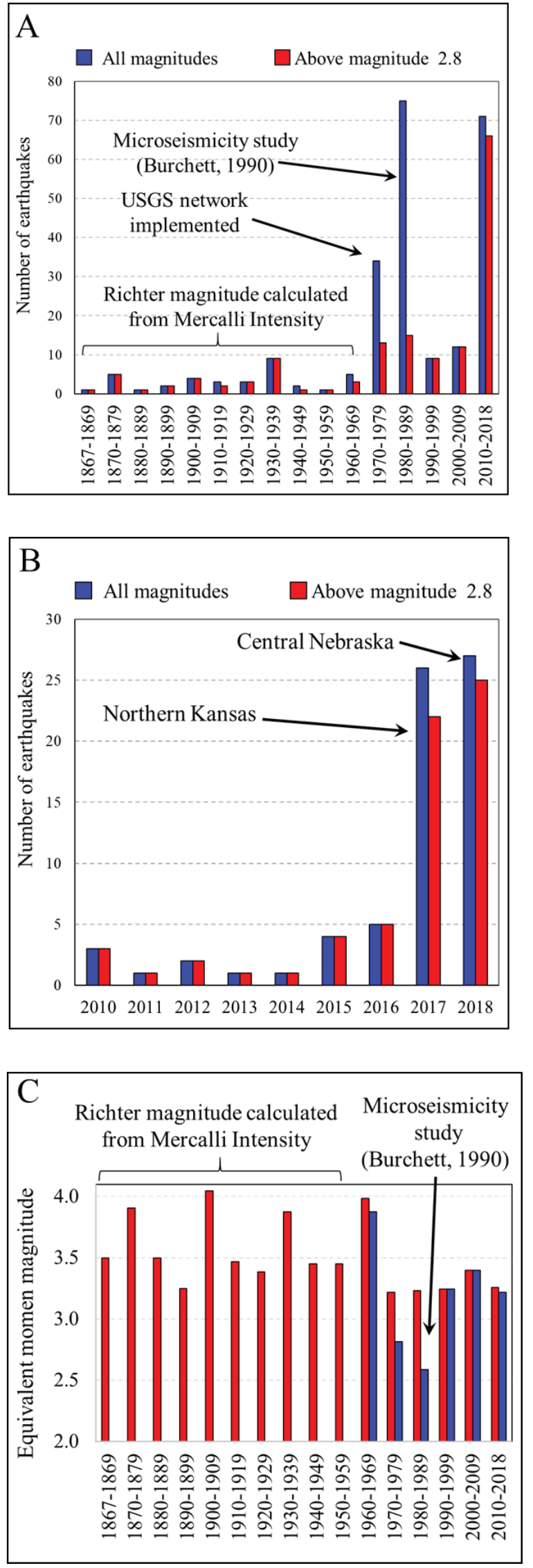

Figure 3.

(A) Number of earthquakes by decade. Blue bars show the total number of earthquakes in database and red bars show the number with an equivalent moment magnitude above 2.8. (B) The number of earthquakes in the current decade. The spike in 2017 is related to a spot in northwestern Kansas (24 out of 26 earthquakes), while the spike in 2018 is focused in the central Nebraska (26 out of 27 events). (C) Average equivalent moment magnitude per decade for the earthquakes shown in part $\mathrm{A}$. 


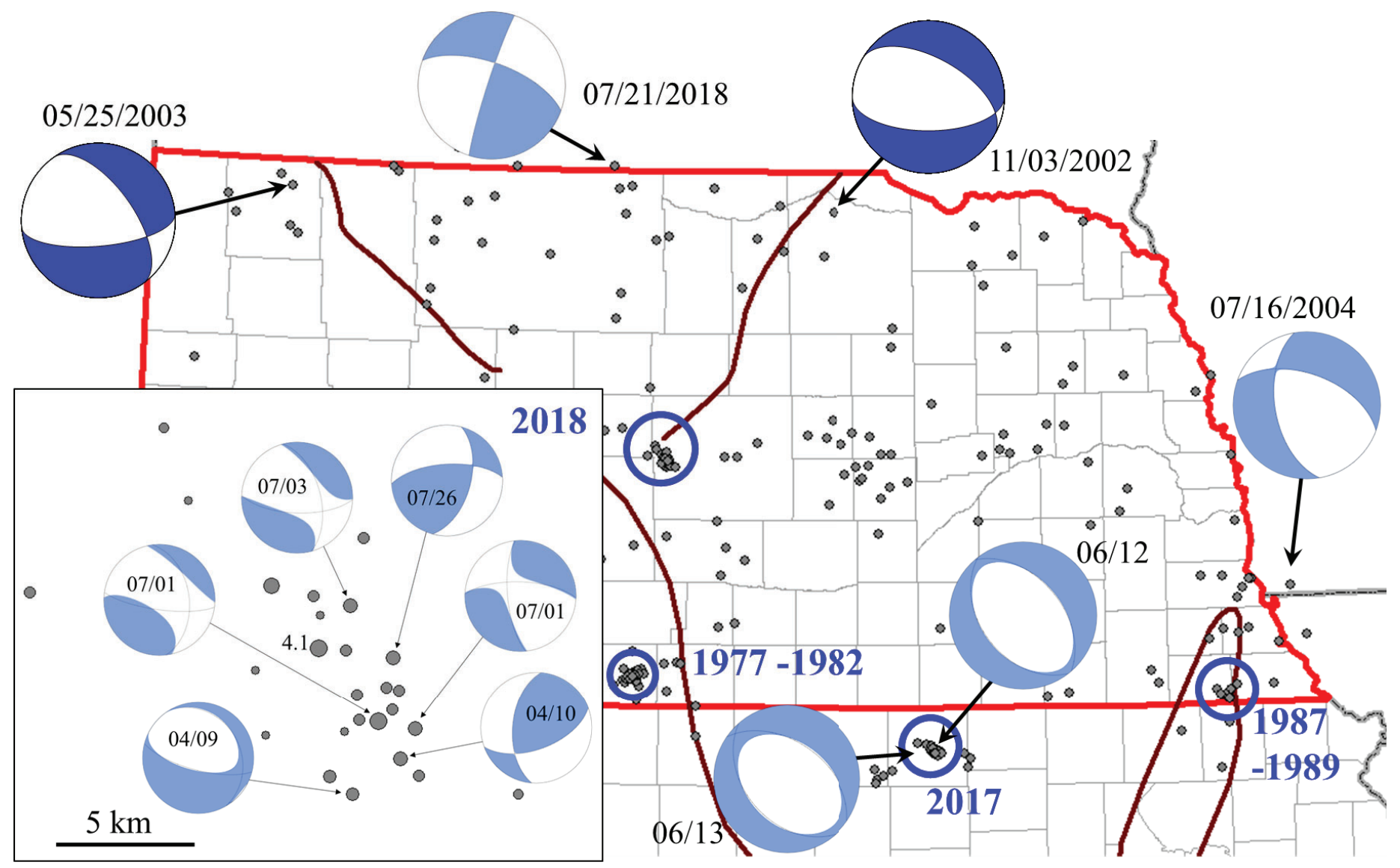

Figure 4. Focal mechanisms and earthquake clusters found for our study area. The beach balls with a light blue color are from the USGS, the darker blue ones are from the SLU catalog. Overall, four spatial clusters were identified, marked with blue circles. See Table 1 for details. The inset shows the focal mechanisms and distribution of events within the 2018 cluster; note the elongate NW-SE oriented trend for this cluster. The minimal size of the earthquake in the inset corresponds to the equivalent moment magnitude of 2.7, while the largest one shows the earthquake with a magnitude of 4.1 .

the sedimentary layer, while the rest were associated with the basement that is approximately $1.1 \mathrm{~km}$ deep in this region. However, that study reported that the first motion data were inconsistent between the events with nearly coincident hypocenters and no correlation was found between injection pressure and earthquake occurrence. Moreover, no well-constrained fault plane could be determined from the recorded earthquakes. With these ambiguities, the study concluded that the observed seismicity probably relates to the injection of the fluids, but there is some evidence of tectonic cause with a reference to the study of Stanley and Wayne (1972).

The second historic earthquake cluster is located over the Nemaha Uplift in southeastern Nebraska (Figs. 1C,
4). There are eight earthquakes in this cluster that occurred between 1987 and 1989. The equivalent moment magnitudes of these eight events range from 2.3 to 2.8 and the depths from 6.1 to $22.31 \mathrm{~km}$. All of these were documented by the microseismicity study reported by Burchett (1990) and are not listed in USGS, ISC or SLU earthquake catalogs. No focal mechanisms were found for the earthquakes in this cluster. The earthquake locations generally align with the known Humboldt fault, confirming that the fault zone is still tectonically active (Burchett et al., 1985). The Humboldt fault strikes N-S approximately along the border between Pawnee and Richardson Counties. The earthquakes are clustered on the western side of the fault in Pawnee County. Most of the oil and gas 


\begin{tabular}{|c|c|c|c|c|c|c|c|}
\hline & & & arthquake cluster & $\begin{array}{l}\text { TABLE } 1 \\
\text { in Nebraska and }\end{array}$ & orthern Kansa & & \\
\hline $\begin{array}{l}\text { Cluster } \\
\text { dates }\end{array}$ & Location & $\begin{array}{l}\text { Number } \\
\text { of events }\end{array}$ & $\begin{array}{c}\text { Equivalent } \\
\text { moment } \\
\text { magnitude range }\end{array}$ & $\begin{array}{c}\text { Cumulative } \\
\text { seismic moment, } \\
\times 10^{15} \mathrm{dyn} \mathbf{~ c m}\end{array}$ & $\begin{array}{c}\text { Depth range, } \\
\text { km }\end{array}$ & $\begin{array}{l}\text { Number of } \\
\text { fixed events } \\
\text { at } 5.0 \mathrm{~km}\end{array}$ & $\begin{array}{c}\text { Averaged depth, } \\
\text { km (excluding } \\
\text { fixed events) }\end{array}$ \\
\hline $1977-1982$ & $\begin{array}{c}\text { SW } \\
\text { Nebraska }\end{array}$ & 32 & $1.5-3.1$ & 3.1 & $0.57-11.09$ & 6 & 3.0 \\
\hline $1982-1989$ & SE Nebraska & 8 & $2.3-2.8$ & 0.8 & $6.1-22.31$ & 3 & 12.6 \\
\hline 2017 & N Kansas & 24 & $2.6-3.7$ & 26.7 & $5.9-16.1$ & 6 & 13.5 \\
\hline 2018 & $\begin{array}{c}\text { Central } \\
\text { Nebraska }\end{array}$ & 26 & $2.7-4.1$ & 58.7 & $1.2-7.7$ & 22 & 4.6 \\
\hline
\end{tabular}

operations in southeastern Nebraska are located in Richardson County and are associated with the Forest City basin to the east of the Nemaha Uplift.

The third cluster is located in Jewell County in northern Kansas (Figs. 1C, 4). There are 24 earthquakes associated with this cluster and all of them occurred in 2017 with the months of April and June being particularly active with 14 and 6 events, respectively. The equivalent moment magnitudes range from 2.6 to 3.7 and the depths range from 5.9 to $16.1 \mathrm{~km}$. The focal depth of the majority of events in this cluster is around $14 \mathrm{~km}$ (17 out of 24 earthquakes), while the rest have uncertain depth that is fixed at $5.0 \mathrm{~km}$. According to the Kansas Geological Survey, the nearest water injection well is approximately 75 $\mathrm{km}$ to the southwest of the cluster (Fig. 1C). Two focal mechanisms were published by USGS for the earthquakes in this cluster (Fig. 4). Both of them are consistent with each other and suggest the presence of an extensional stress regime with a fault striking NW-SE and with a possible dip between $42^{\circ}$ and $49^{\circ}$.

The most recent cluster is located in Custer County in central Nebraska. The first earthquake in this cluster occurred on April 9, 2018, and as of December 3, 2018, a total of 26 events were registered at this location. The largest equivalent moment magnitude of these earthquakes is 4.1 and the smallest one is 2.7. The depths of these events are between $1.2 \mathrm{~km}$ and $7.7 \mathrm{~km}$ with the majority of them being reported as $5.0 \mathrm{~km}$ by USGS online earthquake catalog. According to the Nebraska Gas and Oil Conservation Commission, there are several dry wells near the seismicity cluster that were drilled in the 1960s.
These wells reached the pre-Cambrian basement rocks at depths approximately $1.1-1.2 \mathrm{~km}$ below the surface. The nearest water injection well is approximately $100 \mathrm{~km}$ to the southwest on the other flank of the Cambridge Arch. USGS developed focal mechanisms for six earthquakes in this cluster (see inset in Fig. 4). However, the sense of motions and fault orientations appear to be inconsistent. The focal mechanism released for the first earthquake in this cluster (occurred on April 9, 2018) was aligned with two earthquakes from the 2017 cluster and suggested an overall extensional stress regime with a NW-SE striking fault. However, the earthquake the next day of magnitude 3.7 shows the opposite, i.e., compressional stress distribution with an apparent strike-slip component (Fig. 4). Another event with an apparent oblique reverse faulting style occurred on July 26 (magnitude 3.6), whereas the rest of the earthquakes in July have focal mechanisms consistent with an oblique normal sense of motion.

\section{INTEGRATED ANALYSIS OF GRAVITY AND MAGNETIC FIELDS}

The majority of the earthquakes in our database have shallow focal depths, suggesting basement faulting. We used the basement faults from Burberry and others (2015) for southeastern Nebraska and Northern Kansas (Fig. 1C). The study of Burberry and others (2018) further showed two prominent trends in southeast Nebraska and northeast Kansas; the NE-SW oriented faults that are likely related to the Midcontinent Rift System and Nemaha Uplift, and faults oriented NW-SE, likely related to fabrics from the Central Plains Orogeny. We did not 
A

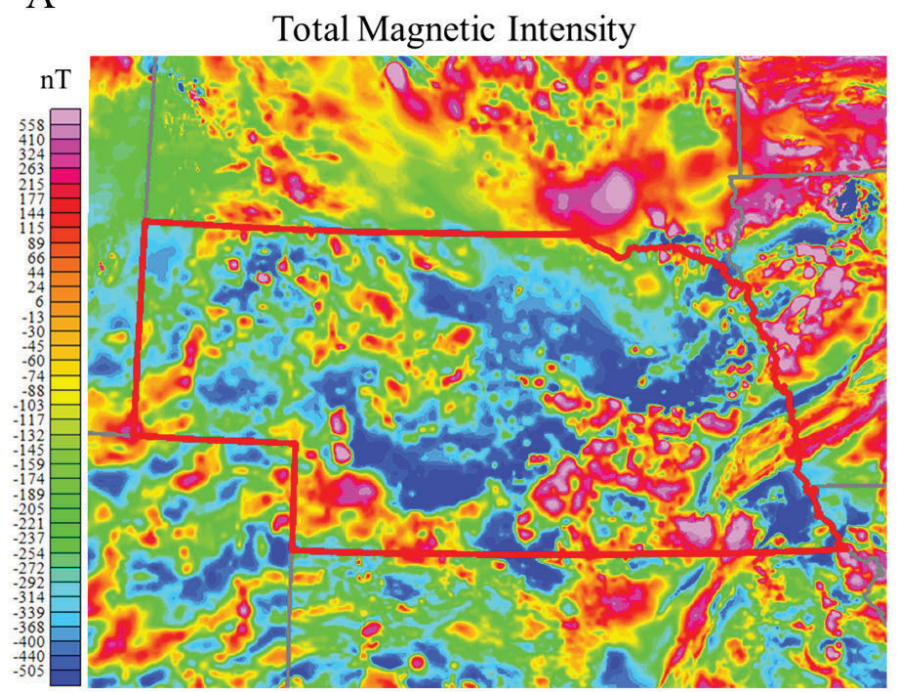

B

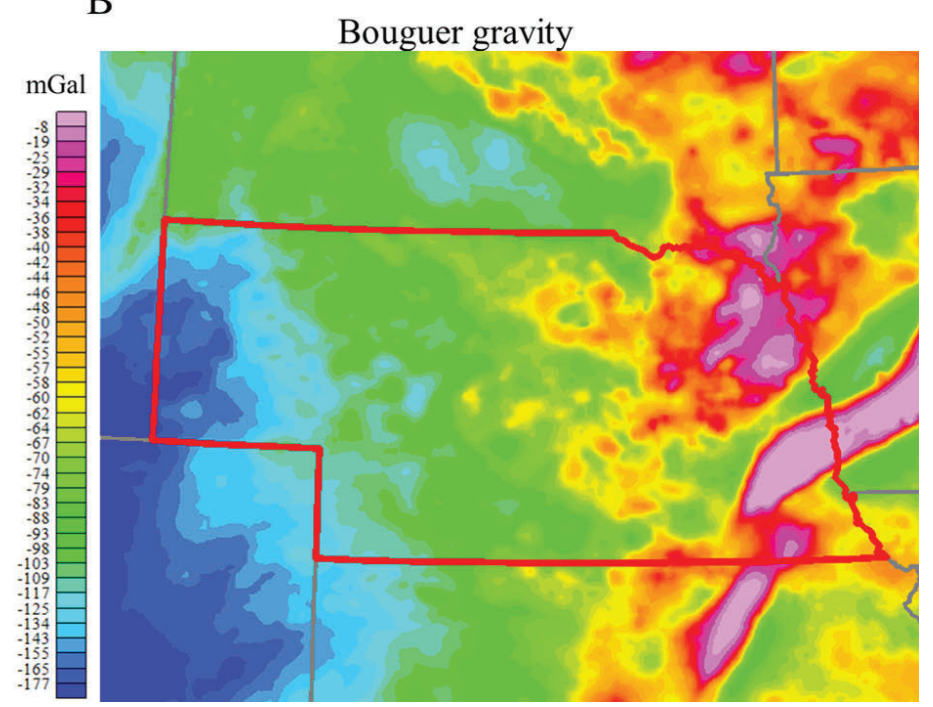

Figure 5. (A) Total magnetic intensity from Bankey et al. (2002), (B) Original Bouguer gravity from Kucks (1999).

find any published basement faults for the western part of Nebraska. These may be mapped using potential fields data (gravity and magnetics) as they change in response to the lateral variations of physical properties of the rocks in the subsurface, i.e., densities and magnetic susceptibilities (Lyatsky et al., 2004).

The basement faults are associated with significant contrasts in the physical properties of the rocks present since denser and more magnetic basement rocks are in contact with low density and generally nonmagnetic sediments. These contrasts in physical properties across the fault will cause variations in both potential fields, referred to as lineaments. However, these signals are relatively small, and need to be enhanced through filtering. The lineaments are interpreted to map the basement faults. Such analysis of airborne magnetic data was performed in Oklahoma (Shah and Crain, 2018), revealing potential seismogenic basement faults that can be reactivated in induced seismicity settings. The confidence in the fault interpretation increases if the lineaments are observed at the same location in both independently recorded potential fields. The spatial alignment of the interpreted fault with recorded seismicity further indicates that the fault has been reactivated.

We utilized gravity data from Kucks (1999) and magnetic data from Bankey and others (2002) shown in Figure 5. In order to highlight the lineaments in potential fields, a series of transformations and corrections was applied to both fields. The gravity map had a regional trend removed that represents the effect of deep density variation at the crust-mantle interface. This regional trend was computed via upward continuation to $100 \mathrm{~km}$ elevation. After it was removed, a tilt derivative filter was applied to the residual gravity anomaly to highlight the effect of the shallow structures, such as basement faults. The magnetic map was reduced to the pole with an inclination of $75.66^{\circ}$ and a declination of $11.25^{\circ}$. Then a tilt derivative filter was applied to the magnetic field as well. Both fields were lowpass filtered with a $5 \mathrm{~km}$ wide window in order to remove some artifacts highlighted by the tilt derivative filter. The filtered residual Bouguer gravity and reduced to the pole magnetic fields are shown in Figure 6.

The filtering highlights the regions where the potential fields show a change in character. As both gravity and magnetic field record the cumulative signals from all the sources in the subsurface, not only the basement faults, but also lateral variations within the sedimentary layer and possible inhomogeneities within the crust, the interpretation of faults in the mixed multiple signals is challenging. We compared the filtered signals with the published faults from Burberry and others (2015; Figs. 1, 6). The following correlations were observed: on magnetic field maps, the faults either follow the magnetic low, or are associated with an abrupt change in magnetic fabric; on gravity 
A

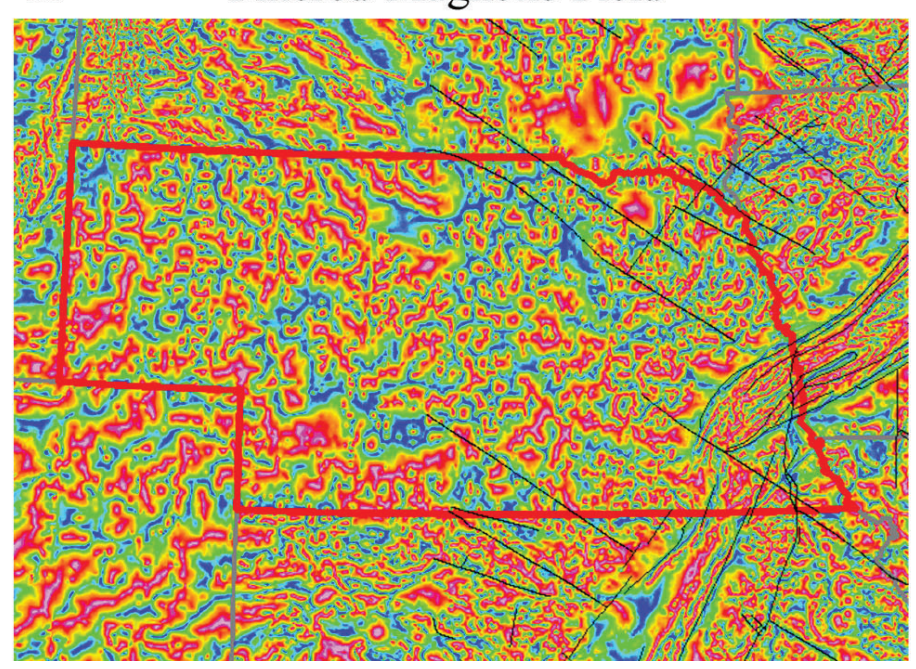

B Filtered Gravity Field

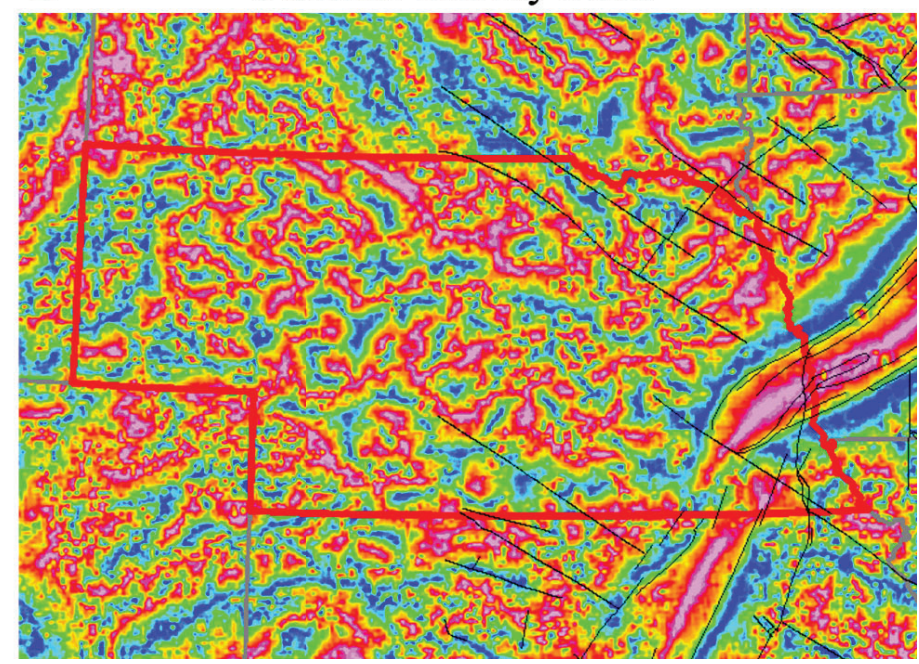

Figure 6. (A) Tilt derivative of reduced to pole magnetic field, (B) Tilt derivative of residual Bouguer gravity. See text for filtering details. The faults from Burberry et al. (2015) are shown in the western part of our study area. The correlation between known faults and distinct features in filtered potential fields (lows in magnetics, gravity gradient and abrupt changes in pattern for both) was used to interpret the basement faults for the rest of the area.

field maps the faults either are aligned with the gradient of the filtered gravity anomaly or also mark sharp changes in the pattern of anomalies. As the filtered magnetic map (Fig. 6A) offers better resolution than the filtered gravity map (Fig. 6B), we guided our interpretation with the magnetics and used gravity as supporting evidence. We used the observations listed above as criteria for the interpretation of basement faults for the entire study area (Fig. 7). We interpreted the faults only in the regions where lineaments were coincident in both gravity and magnetic fields. We also used the consistency of their spatial trends, agreement with earthquake locations and focal mechanism orientations, and the overall correlation with the published faults maps (Burberry et al., 2015) as a guidance for our interpretation.

The initial basement faults were mapped from the integrated analysis of potential fields (Searls et al., 2017; Guthrie et al., 2018) prior to the cluster of earthquakes in central Nebraska starting in April 2018. This swarm of earthquakes is aligned with interpreted faults, thus validating our methodology. Figure 8 shows the rose diagram composed for our interpreted lineaments. There are two pronounced orientations of lineaments visible in the rose diagram, a NE-SW trend and a NW-SE trend. The
NE-SW trend is the same trend as the Mid-Continent rift and associated structures from the Penokean Orogeny (Burberry et al., 2018) and the NW-SE trend is similar to that within the Central Plains Orogen (op. cit.). The 2018 cluster of earthquakes from Nebraska falls along a NWSE oriented trend (red line in Fig. 8 - orientation $313^{\circ}$ ), strengthening the case that this cluster is associated with one such basement fault. Similarly, the Jewell County cluster of events falls on a NW-SE oriented trend (red line in Fig. 8, orientation $297^{\circ}$ ) and is likely to be associated with a similar basement fault in north-central Kansas. The overall location of these and other earthquake events along the interpreted faults (refer back to Fig. 7C) validates our results and proves the value of the integrative analysis that combines several independent geophysical and geological datasets.

\section{DISCUSSION}

Our earthquake database for Nebraska and parts of adjacent states suggests that small earthquakes occur in the study area regularly and are generally spread out throughout the state. However, we have identified several earthquake clusters (Fig. 4). The oldest one, which was active in southwestern Nebraska from 1977 to 1982, appears 
to be induced by enhanced oil and gas recovery from the Sleepy Hollow oil field (Rothe and Lui, 1983; Evans and Steeples, 1987), although its origin can also be related to the tectonically active Cambridge Arch (Stanley and Wayne, 1972). The second one, occurring between 1982 and 1989 in southwestern Nebraska, relates to the tectonically active Humboldt fault (Burchett et al., 1985). The 2017 cluster in northern Kansas, followed by the one in central Nebraska in 2018, show an increasing trend in magnitude (Table 1), with the largest event being of magnitude 4.1 in Nebras$\mathrm{ka}$ in July 2018. These clusters are $250 \mathrm{~km}$ apart and do not appear to be aligned with major tectonic structures such as the Chadron Arch; therefore, no tectonic origin can be implied, as for example, for the cluster over the Humboldt fault. Both 2017 and 2018 earthquake clusters are also distant from known water injection wells that can trigger induced seismicity similar to the proposed cause of the cluster over the Sleepy Hollow oil field in Nebraska, or to induced seismicity in northern Oklahoma and southern Kansas (Keranen et al., 2013; McNamara et al., 2015; Walsh and Zoback, 2015; Rubinstein et al., 2018; Hincks et al., 2018; Peterie et al., 2018). Despite the cause of these sudden seismicity clusters, they represent seismic hazard and must be included in the next generation of the seismic hazard assessments and forecast.

The focal depth of the earthquakes suggest that they are related to reactivation of shallow basement faults (approximate depth to pre-Cambrian basement in both regions is $-1.1 \mathrm{~km}$ ). The tectonic stress map of the U.S. (Heidbach et al., 2016) shows no data for the state of Nebraska. The nearest stress data in Oklahoma suggests an overall strike-slip regime related to induced seismicity. Zoback and Zoback (1980) show a map of the midcontinent with a greatest compressional stress oriented NE-SW. None of this is consistent with any of the focal mechanisms in the study area. However, Calais and others (2006) use global positioning satellite velocities to show an overall extensional regime in the Nebraska area, with the principal extensional stress oriented N-S. This

\section{A Filtered Magnetic Field}

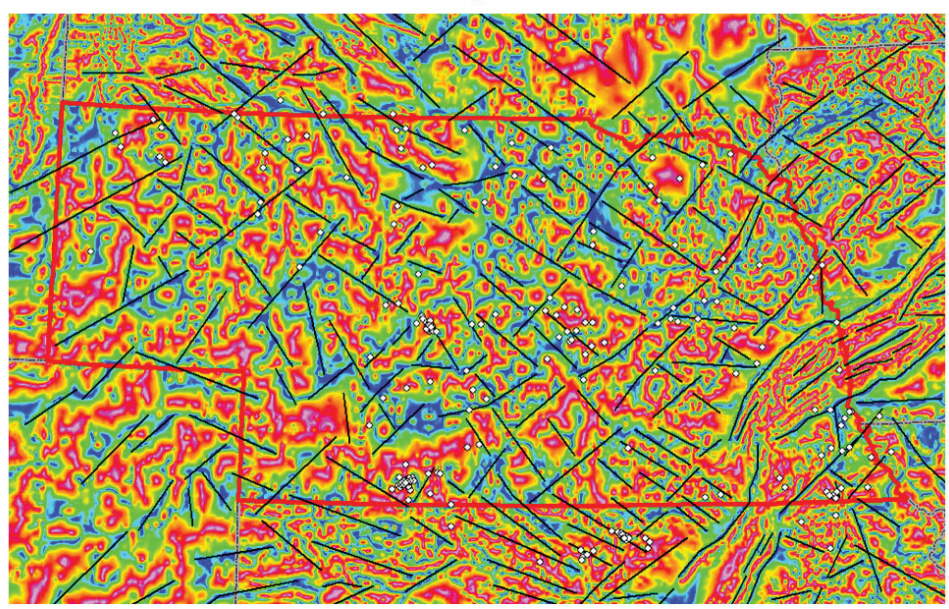

B Filtered Gravity Field

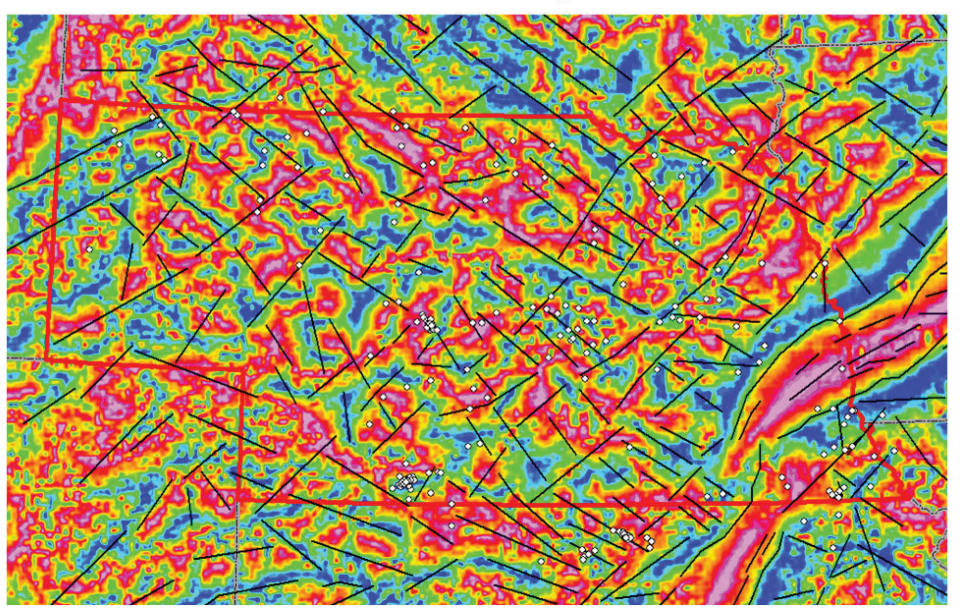

C Interpreted Faults

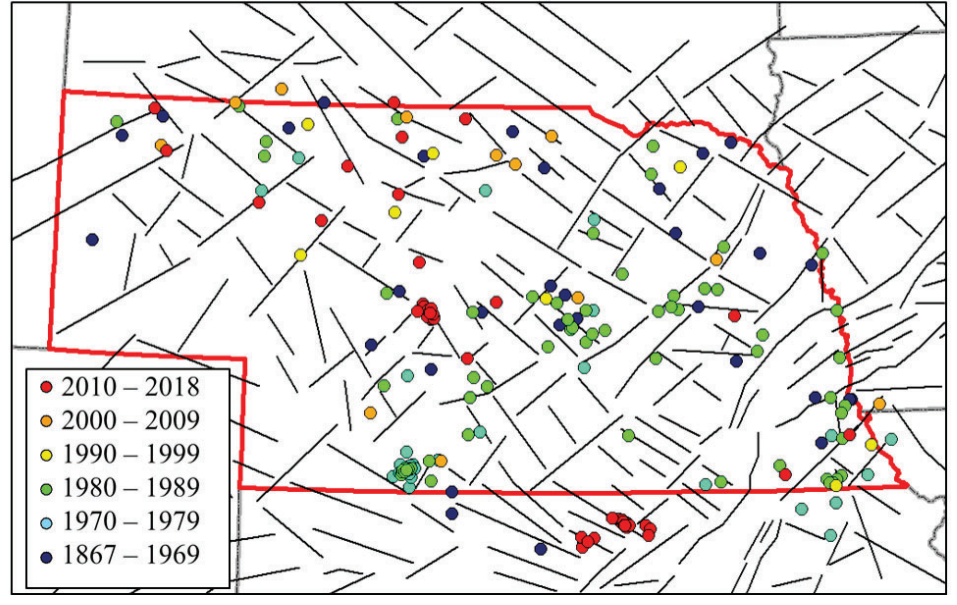

Figure 7. Filtered magnetics (A) and gravity (B) with interpreted lineaments and earthquakes, $(C)$ Interpreted subsurface faults with earthquakes color coded by decade as in Figure 2. 
may be responsible for reactivation of NW-SE trending basement faults in extension and for most of the focal mechanisms observed in the 2018 cluster of events (see inset in Fig. 4).

The cause of the sudden spikes in seismicity observed in our study area in 2017 and 2018 is unknown and needs further investigation. The two possible explanations include natural tectonic forces, or induced seismicity due, possibly, to petroleum extraction operations. The tectonic origin of the stress is supported by the fact that the recorded seismicity spikes are located far away from known water injection wells that may trigger some induced seismicity. However, the controversies observed in the interpretation of the focal mechanisms for the 2018 cluster are similar to the ones described by Evans and Steeples (1987) over the 1977 to 1982 earthquake cluster over the Sleepy Hollow oilfield with a potentially induced origin. In contrast, the focal mechanisms of induced earthquakes in Oklahoma show striking consistency (Alt and Zoback, 2017). In order to study further seismicity in central Nebraska, the USGS established two portable seismic stations near the 2018 cluster. The geophysical research team of the University of Nebraska also intends to install a temporary seismic network around the ongoing seismicity region in central Nebraska to record further earthquakes. These records will help to constrain the focal depths and the faulting style, as well as to investigate possible causes of the sudden seismicity in the region.

\section{CONCLUSIONS}

A sudden spike in seismicity is recorded in central Nebraska in 2018 and in northern Kansas in 2017. A general magnitude increase with time is noted, representing a potential seismic hazard. Both clusters are located at least $75 \mathrm{~km}$ from water injection wells that can cause induced seismicity. An earthquake database for the state of Nebraska and the parts of adjacent states was composed from various sources, to test whether the recent clusters match historic seismicity. Two historic earthquake clusters were observed. One is thought to relate to petroleum

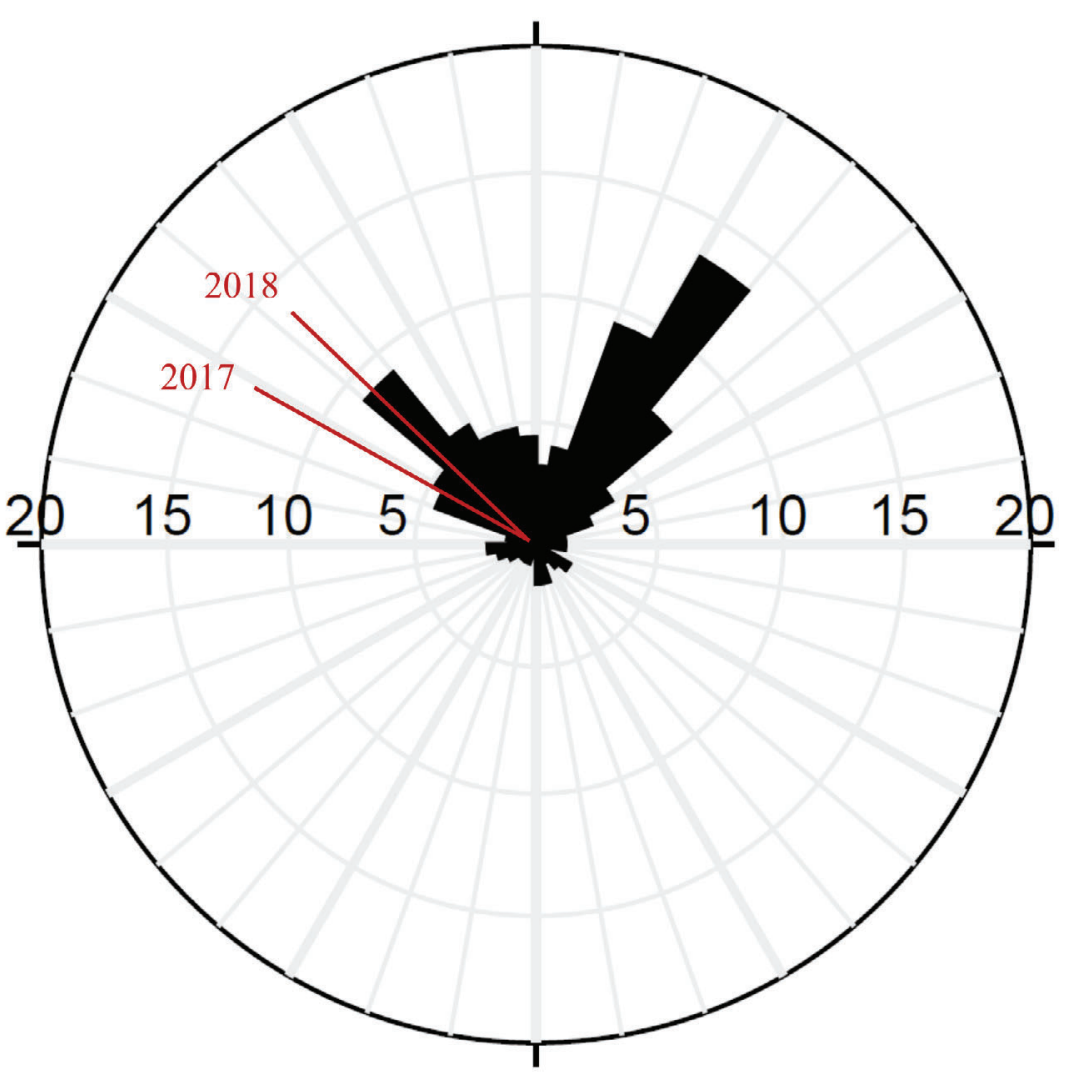

Figure 8. Rose diagram showing the trends of all basement lineaments mapped in the study area. Two prominent trends can be discerned; a NE-SW trend correlating to the Mid-Continent Rift and surrounding areas, and a NW-SE trend correlating to fabrics of the Central Plains Orogen. Red lines mark the trends of the earthquake clusters in 2018 and 2017; correlating with a Central Plains Orogen-related series of basement fault strands.

operations at the Sleepy Hollow oil field, the second to the geologically active Humboldt fault. Basement lineaments were interpreted from an integrated analysis of gravity and magnetics; many of these lineaments are associated with earthquakes and are likely to represent basement faults. The two recent clusters that are $250 \mathrm{~km}$ apart appear to be aligned along similar basement fault trends and therefore may be reactivating in a similar, albeit currently unknown, stress regime.

There are no data on the current World Stress Map for Nebraska. The overall stress inferred from a few published focal mechanisms in our earthquake database is extensional, generally oriented NE-SW. However, there is some ambiguity in the stress regime revealed by the latest 
earthquake cluster in central Nebraska as two out of six focal mechanisms published by USGS suggest compressional stress, oriented NW-SE. The cause of this sudden spike in seismicity is still not clear. More seismic stations are necessary to better detect the faulting style and to investigate possible causes.

\section{ACKNOWLEDGEMENTS}

This research was funded in part by the University of Nebraska, Grants-in-Aid program (grant number \# 260514-9001-006). We would like to thank R.M. (Matt) Joeckel for sharing his wealth of knowledge on Nebraska geology. We are also extremely grateful to three anonymous reviewers for their detailed analysis of the paper.

\section{REFERENCES}

Alt, R.C. and Zoback, M.D., 2016, In situ stress and active faulting in Oklahoma. Bulletin of the Seismological Society of America, v. 107, p. 216-228

Bankey, V., Cuevas, A., Daniels, D., Finn, C.A., Hernandez, I., Hill, P., Kucks, R., Miles, W., Pilkington, M., Roberts, C., Roest, W., Rystron, V., Shearer, S., Snyder, S., Sweeney, R., Velez, J., Philips, J.D., and Ravat, D., 2002, Digital data grids for the magnetic anomaly map of North America: U.S. Geological Survey, U.S. Geological Survey Open-File Report $02-414$

Burberry, C.M., Swiatlowski, J.L., Searls, M.L., and Filina, I., 2018, Joint and lineament patterns across the midcontinent indicate repeated reactivation of basement-involved faults: Geosciences, v. 8, p. 215.

Burberry, C.M., Joeckel, R.M., and Korus, J.T., 2015, Post-Mississippian tectonic evolution of the Nemaha Tectonic Zone and Midcontinent Rift System, SE Nebraska and N Kansas: The Mountain Geologist, v. 52, p. 47-73.

Burchett, R., Luza, K., Van Eck, O., and Wilson, F., 1985, Seismicity and tectonic relationship of the Nemaha uplift and Midcontinent geophysical anomaly: Special publication 85-2, Oklahoma Geological Survey, 37 p.

Burchett, R.R. 1990, Earthquakes in Nebraska: Educational circular 4a: Conservation and Survey Division, University of Nebraska-Lincoln, 20 p.
Calais, E., Han, J.Y., DeMets, C., and Nocquet, J.M., 2006, Deformation of the North American plate interior from a decade of continuous GPS measurements: Journal of Geophysical Research: Solid Earth, vol. 111, no. B6, p. B06402

Coleman, J.L., Jr., and Cahan, S.M., 2012, Preliminary catalog of the sedimentary basins of the United States: U.S. Geological Survey Open-File Report 2012-1111, 27 p.

Guthrie, K., Filina, I., Searls, M., and Burberry, C.M., 2018, Earthquake database for Nebraska as a constraint for Midcontinent Rift related faults: Geological Society of America Abstracts with Programs, v. 50, no. 4, DOI: 10.1130/abs/2018NC-312951.

Heidbach, O., Rajabi, M., Reiter, K., Ziegler, M., and WSM Team, 2016, World Stress Map database release, GFZ Data Services, DOI:10.5880/ WSM.2016.001.

Hincks, T., Aspinall, W., Cooke, R., and Gernnon, T., 2018, Oklahoma's induced seismicity strongly linked to wastewater injection depth: Science, v. 359, p. 1251-1255.

International Seismological Center, 2018, ICS Bulletin, http://www.isc.ac.uk/iscbulletin/ (accessed 2018).

Kanamori, H., 1978. Quantification of earthquakes. Nature, v. 271, p. 411.

Kansas Geological Survey, 2018, Oil and Gas Well Database, http://www.kgs.ku.edu/Magellan/Qualified/ index.html (accessed 2018).

Keranen, K.M., Savage, H.M., Abers, G.A, and Cochran E.S., 2013, Potentially induced earthquakes in Oklahoma, USA: Links between wastewater injection and the $2011 \mathrm{Mw} 5.7$ earthquake sequence: Geology, v. 41, p. 699-702.

Kucks, R.P., 1999, Bouguer gravity anomaly data grid for the conterminous US: U.S. Geological Survey Digital Data Series, DDS-9.

Lyatsky, H., Pana, D., Olson, R. and Godwin, L., 2004, Detection of subtle basement faults with gravity and magnetic data in the Alberta Basin, Canada: A data-use tutorial: The Leading Edge, v. 23, p. 1282-1288.

Marsh, S., and A. Holland, 2016, Comprehensive fault database and interpretive fault map of Oklahoma: Oklahoma Geological Survey Open-File Report OF2-2016, Norman, Oklahoma, 15 p. 
Mueller, C.C., Hopper, M.G. and Frankel, A.D., 1997. Preparation of earthquake catalogs for the National Seismic-Hazard Maps: contiguous 48 states: U.S. Geological Survey Open-File Report 97-464, 36 p.

McNamara, D. E., Benz, H. M., Herrmann, R. B., Bergman, E. A., Earle, P., Holland, A., Baldwin, R., and Gassner, A., 2015, Earthquake hypocenters and focal mechanisms in central Oklahoma reveal a complex system of reactivated subsurface strikeslip faulting: Geophysical Research Letters, v. 42, p. 2742-2749.

Nebraska Oil and Gas Conservation, 2018, GIS Data Mining, http://www.nogcc.ne.gov/RBDMSDataMining/(S(523n0q3uidnunugxboy5upra))/ (accessed 2018).

Peterie, S. L., Miller, R. D., Intfen, J. W., and Gonzales, J. B., 2018, Earthquakes in Kansas induced by extremely far-field pressure diffusion: Geophysical Research Letters, v. 45, p. 1395-1401.

Petersen, M.D., Moschetti, M.P., Powers, P.M., Mueller, C.S., Haller, K.M., Frankel, A.D., Zeng, Y., Rezaeian, S., Harmsen, S.C., Boyd, O.S., Field, N., Chen, R., Rukstales, K.S., Luco, N., Wheeler, R.L., Williams, R.A., and Olsen, A.H., 2014, Documentation for the 2014 update of the United States national seismic hazard maps: U.S. Geological Survey Open-File Report 2014-1091, 243 p.

Petersen, M.D., Mueller, C.S., Moschetti, M.P., Hoover, S.M., Rukstales, K.S., McNamara, D.E., Williams, R.A., Shumway, A.M., Powers, P.M., Earle, P.S., Llenos, A.L., Michael, A.J., Rubinstein, J.L., Norbeck, J.H., and Cochran, E.S., 2018, Data Release for 2018 one-year seismic hazard forecast for the central and eastern United States from induced and natural earthquakes: U.S. Geological
Survey data release, DOI: https://doi.org/10.5066/ F7Cf9PC4.

Rothe, G.H., and Lui, C.Y., 1983, Possibility of induced seismicity in the vicinity of the Sleepy Hollow Oil Field, southwestern Nebraska: Bulletin of the Seismological Society of America, v. 73, p. 1357-1367.

Rubinstein, J. L., W. L. Ellsworth, and S. L. Dougherty, 2018, The 2013-2016 Induced Earthquakes in Harper and Sumner Counties, Southern Kansas, Bull. Seismol. Soc. Am., v. 108, 674-689.

Searls, M., Filina, I., Burberry, C.M., and Quartoroli, E., 2017, Midcontinent Rift structures in SE Nebraska: Geological Society of America, Abstracts with Programs, v. 49, no. 6, DOI: 10.1130/ abs/2017AM-308250.

Shah, A. K., and Crain, K., 2018, Aeromagnetic data reveal potential seismogenic basement faults in the induced seismicity setting of Oklahoma, Geophysical Research Letters: v. 45, p. 5948-5958.

Stanley, K.O., and Wayne, W.J., 1972, Epeirogenic and climatic controls of early Pleistocene fluvial sediment dispersal in Nebraska: Geological Society of America Bulletin, v. 83, p. 3675-3690.

St. Louis University, 2018, Earthquake Center, http://www.eas.slu.edu/Earthquake_Center/ (accessed 2018).

U.S. Geological Survey, 2018, U.S. Geological Survey Earthquake Catalog, http://earthquake.usgs.gov/ earthquakes/ (accessed 2018).

Walsh, F.R.I., and Zoback, M.D., 2015, Oklahoma's recent earthquakes and saltwater disposal, Sci. Adv., 1 (e1500195).

Zoback, M.L., and Zoback, M., 1980, State of stress in the conterminous United States: Journal of Geophysical Research, v. 85, p. 113-615. 